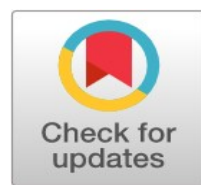

\title{
The influence of undervaluation, free cash flow, leverage and dispersion of ownerships toward company's stock repurchase (An empirical study of Indonesia stock exchange public listed companies)
}

\author{
Cholifah Bahri ${ }^{1}$, Mahsina S. $\mathrm{E}^{2 *}$, Asmie Poniwati ${ }^{3}$ \\ 1, 2,3 University of Bhayangkara, Surabaya, Indonesia
}

\author{
Keywords \\ Undervaluation \\ Free cash flow \\ Leverage \\ Dispersion of ownerships \\ Stock repurchase
}

Received: 15 January 2017

Accepted: 5 July 2017

Published: 9 October 2017

\begin{abstract}
The objective of this research is to study the influence of undervaluation, free cash flow, leverage and dispersion of ownerships toward company's stock repurchase (An empirical study of Indonesia stock exchange public listed companies). Many researchers have shown that the Stock repurchase is the best alternativ for the company to recover the decrease of stock value by doing 'buyback' of the stock from the market which is mostly caused by the negative sentiment, especially during the crisis. The research methodology approach has used 26 samples of manufacturing companies by using a purposive sampling method which means its sampling technique is based on the 'sample criteria'. Samples are from the public listed companies which are listed on Indonesia Stock Exchange (IDX) during the period of 2010-2014. The major criterion is that companies are consistently publishing their stock repurchase announcement. In order to conduct the hypothesis test, it used a multiple linear regression analysis to analyze the influence of independent variables undervaluation, free cash flow, leverage and dispersion of ownerships toward stock repurchase. The findings show that $R$-Square amount is 0.783 , which means that the independent variables have influences of $78.3 \%$ toward its dependent variable. And, $F$-test shows the significant simultaneous impact of undervaluation, free cash flow, leverage and dispersion of ownerships toward company's stock repurchase. And, as per $t$-test only leverage, and dispersion of ownerships have a partial influence toward company's stock repurchase. Undervaluation, and free cash flow show negative and above significant level of $(\alpha)$, or more than the confidence level of $95 \%$. This study may contribute to providing an overview of the factors of undervaluation, and free cash flow ownerships toward company's stock repurchase in Indonesia which can be used by the managers and shareholders decision-making and also supporting the best fundamental preparation on stock repurchase.
\end{abstract}

(C) 2017 The Author(s). Published by TAF Publishing.

\section{INTRODUCTION}

One form of corporate action that is already popular in foreign capital markets is a stock repurchase or stock buyback for the more popular term in the Indonesia capital market IDX. Stock repurchase of shares is stock repurchase by the company that published it in the open market or through a buyback offer (Horne \& Wachowicz,
2005). Although open market stock repurchases are increasingly common and have recently received much publicity, they are surprisingly difficult to measure (Jagannathan, Stephens \& Weisbach, 2000). A firm can legally repurchase its own stock whenever it chooses without announcing its intention to do so; however, by announcing a repurchase program the firm protects itself from liability

\footnotetext{
${ }^{*}$ Corresponding author: Mahsina S. E

†Email: mahsina_se@hotmail.com
} 
under BAPEPAM regulation which currently has 2 (Two) major rules, first, rule of Bapepam-LK Nomor X.K.1 on the regulation of BAPEPAM No. Peraturan (1996) Keputusan Ketua Bapepam No.Kep-86/PM/1996 about the Open information to public and second, rule of Peraturan Nomor XI.B.2. (1998) of the regulation Keputusan Ketua Bapepam No.Kep-45/PM/1998. Its related with to 'Buyback' stock procedures which is stock repurchase should base on the agreement of Meeting of Shareholders of public company Rapat Umum Pemegang Saham (RUPS).

Many of the research results of stock repurchase indicated that the stock repurchase would be followed by an increase in the company's share price. It may indicate that positive reaction was given by the market related to the theory of information signaling (Vermaelen, 1981). It has different conditions with the foreign companies which have conducted many of the stock repurchase actions. Indonesia local company has rarely to conduct the 'buyback' action (Kurniawan \& Moeljadi, 2013). Stock buyback program is conducted by a corporation having the strong cash flow and the companies running their course on stock buyback action should have a healthy cash flow. Researchers have indicated that stock repurchase is an important financial policy instrument that could affect other multiple corporate decisions, such as payout, structure of capital, investment policies, and management compensation policies (Pacheco \& Raposo, 2007; Purnamasari \& Fitdiarini, 2016). In addition, stock repurchase are becoming highly important actions in most developed stock market (Andriosopoulos \& Lasfer, 2015; Grullon, Michaely \& Swaminathan, 2002; Ikenberry, Lakonishok \& Vermaelen, 2000; Stephen \& Weisbach, 1998). Why do firm need stock repurchase? Jensen (1986) has commented that firms conduct the stock repurchase in order to distribute excess cash flow (free cash flow). Stephens \& Weisbach (1998) also have found that stock repurchase and level conditions of company's cash flow have a positive relationship. Unfortunately, research on company's action in capital market in Indonesia capital market is still limited for such kind merger research, cash dividend, and rights issue (Kurniawan \& Moeljadi, 2013) and this research is including the topic which is carried out only on a group of companies towards stock buyback research topics (stock repurchase) (Bhana, 2007; Hussin, Ahmed \& Ying, 2010; Hyderabad, 2009; Kinsler \& Bacon, 2008). And, only a few researches that focused on the stock repurchase and its factors of influence are there, because not only a limited number of companies perform a stock repurchase during current period of research which is 2010-2014, but also lack of research focuses on the individual of the 4 (Four) factors of undervaluation, leverage, free cash flow, and dispersion of ownerships having influence toward its stock repurchase. It is a research gap and it is deemed necessary to do the research on it. In 2008, Indeks Harga Saham Gabungan (IHSG) declined until it reached 1.089 and then it was closed at 1.111 on October, 28. Negative sentiment in the Indonesia market stock exchange has made the government focus on it. And, Indonesia government has considered that it will need some actions to anticipate it, and it's purposed to calm the market. One of its government actions was doing 'Buyback' towards the shares of Indonesia state owned companies and it was considered workable to make the stock price stable. Therefore, based on the above background, this research is purposed to conduct an overview of the factors of undervaluation, leverage, free cash flow, and dispersion of ownerships toward company's stock repurchase in Indonesia which can be utilized by the investors/managers for decision making and fortifying the best key of preparation on stock repurchase. Furthermore, this exploration is to give a comprehension to the public, particularly to investors that the stock repurchase is legitimate and it has been demonstrated that stock repurchase is a route for company to recover the diminishing stock value by doing 'buyback' from the market which is mostly caused by the negative sentiment from the investors, particularly during the crisis.

\section{LITERATURE REVIEW}

\section{Undervaluation toward Stock Repurchases}

Undervalued is a kind of financial terminology which refers to the type of security or others towards the investment that it sells at a price considered to be below the investment's true real value (Investopedia, 2015). Many researches have found about the influences of undervaluation on the stock repurchase including the research from Adel (2014) which has explained about the theory of "market timing". It is described that share repurchase action is taken whenever the firm's value is undervalued. Also, Firth \& Yeung (2005) also described that the impression of underestimated shares and the accessibility of money surplus are turning into the main considerations in the choice for the firms to do the stock repurchase. Hence, the undervalue motives is a part of the explanations for the management of a company doing 'buyback' in order to recover its stock's value. 
These reviews were also validated by Brockman \& Chung (2001), Cook, Krigman \& Leach (2003), and Fu, Chung, Luk \& Ng (2007) who affirmed that in the decision of the "market timing" theory which characterizes that the repurchase is on account using asymmetric information between the investors and managers once the firms stock is undervalued, both investors and managers will perform the stock repurchase. In what it concerns the moment of share repurchase, and literature has affirmed the availability of particular waves or cycles of this symptoms, for some different reasons and motives. One of those different reasons and motives is when company's stock is undervalued and then managers will consider to repurchase as an appropriate action, or a necessity to adjust the market price (Amelia, 2016; Brav, Graham, Harvey \& Michaely, 2005; Hosban, 2016).

\section{Free Cash Flow toward Stock Repurchases}

According to Heydary, Mirza \& Javadghayedi (2014) Free cash flow is a requirement to measure the execution of organizations which demonstrates the measure of money possessed by the organization after its costs keeps expanding the properties and different costs required. Heydary et al. (2014) commented that in order to increase the stockholder's asset opportunities, the free cash flow is becoming an essential thing. Therefore, in order to fulfill it, shareholders have to decide to distribute the excess of cash flow to increase the ownership structure by doing 'buyback' as well as the management has to use its free cash flow for 'buyback' to recover the undervalued stock. This has also been supported by Jensen (1986) research that it states the companies which with surplus free cash flow and less positive investment opportunity will have issues on the agency cost; therefore, share repurchase is a method to help minimize the agency cost. The most popular theory about the "buyback' phenomenon (share repurchase/stock repurchases) is the Signaling theory (Bharucha, 2016; Hsu \& Utami, 2016; Lie, 2005; Peyer \& Vermaelen, 2008). The managers have to announce that in a positive perspective the shares are undervalued, and the free cash flow prescribes the distribution of cash-flow to shareholders for stock repurchases instead of using it in inefficient projects (Grullon \& Michaely, 2004). And, the best hypothesis related to it, is from a reference research belonging to Liang, Chan, Lai \& Wang (2013) who studied the motivational factors behind the choice to repurchase shares as a major assets. The analysis of Liang et al. (2013) states that the researchers pick the variables of firm's age, its size, sales and dividends and use as principle pointers on measuring price ratio and free cash flow ratio.
The main conclusion of the study is that firms in the growth phase take the decision to repurchase their shares/stocks with the motivation of signaling, while many mature companies choose to buyback in order to use their cash surplus (Liang et al., 2013).

\section{Leverage toward Stock Repurchases}

Some researchers such as Dittma (2000), Ofer \& Thakor (1987), Wansley, Lane \& Sarkar (1989) have found that in order to increase the leverage of the firms one may conduct the stock repurchases by diminishing an outstanding equity towards an ideal level that could minimize agency and financing costs. Also, some existing studies of share repurchases in general, have found for positive market responses toward its repurchase announcements. Including that the research stated that increasing leverage might have a positive signaling motivation of management in order to decide the 'buyback" of company's shares. Those research findings are also supported by (Chan, Ikenberry, Lee \& Wang, 2010; Dann, 1981; Grullon \& Michaely, 2004; Ikenberry et al., 2000; Vermaelen, 1981). Based on the hypothesis, for some different reasons the positive price responses could increment by utilizing such as picking up a tax advantage for dividend substitution purposed, expanding leverage and signaling the undervaluation of companies' equity. Also, Grullon et al. (2002) declared that in order to adjust the leverage ratio, some firms may choose the contrasting option of stock repurchases.

\section{Dispersion of Ownerships toward Stock Repurchases}

There are only a few studies that expressly look at the relationship between ownership structure and share repurchases. This in spite of the way that the start of a repurchase plan is a basic corporate occasion could change the ownership composition significantly and as time goes on it perhaps impacts the estimation of a firm through corporate governance (Skjeltorp \& Odegaard, 2004). Ownership structure may have an effect on shareholders so as to take control of the company. Ownership structure also shows up likewise to be connected to stock repurchases (Liljeblom \& Pasternack, 2006). Ginglinger \& L'Her (2006) stated that the market response to the announcement of stock repurchase programs differs with ownership structure, to such a degree that market reacts more insistently when the firm has large foreign ownership and when no single shareholder can overwhelm the decision making and hence utilize repurchases for minority seizure purposed. According to El Houcine (2013) there are a few researches 
which investigate the relationship between the ownership structure and the company's policy on repurchasing their own shares. And, the aftereffects of the examination have demonstrated that it has a positive relationship with the managerial ownerships toward the repurchases which fur- thermore infers supporting the manager's.

\section{RESEARCH MODEL}

Based on the research background and the theory above, the research model is reflected in Figure 1.

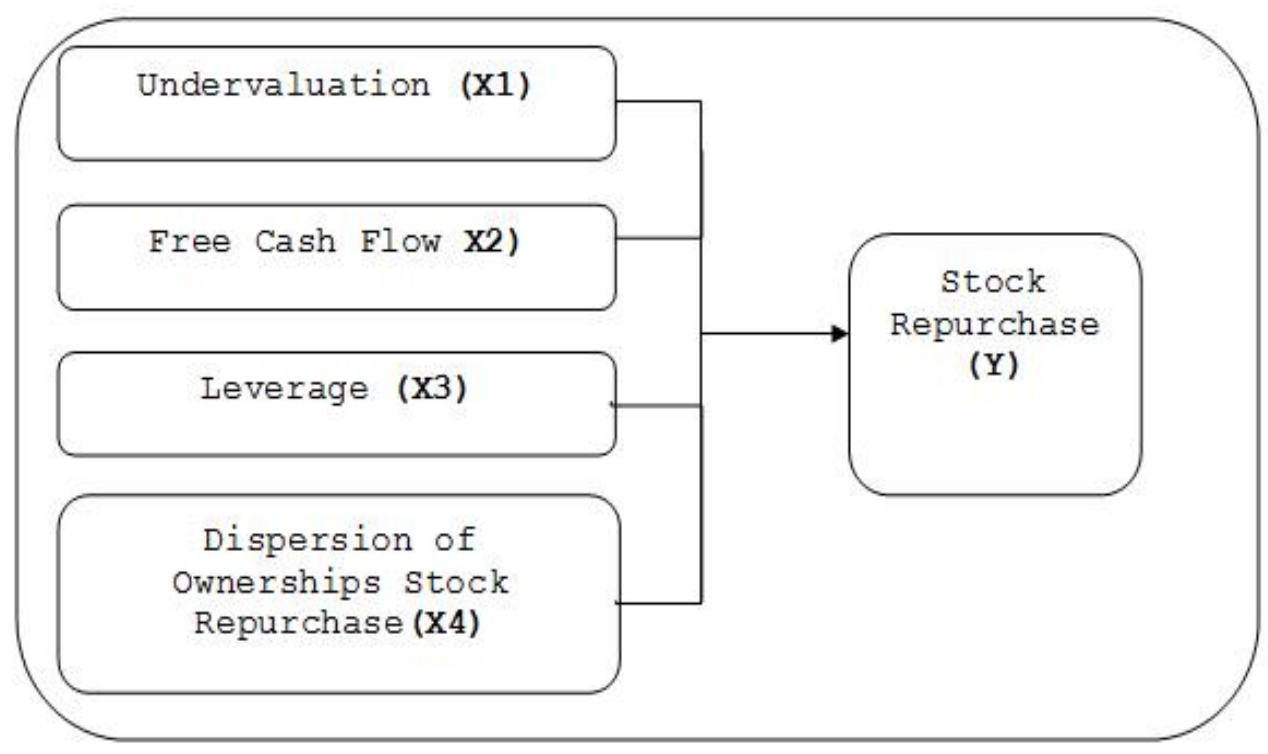

FIGURE 1. Research model

\section{Research Hypothesis}

Based on theory, previous studies and the research model outlined, this study makes hypotheses to examine the relationship between variables:

H1: Undervaluation $(X 1)$, free cash flow $(X 2)$, leverage $(X 3)$ and dispersion of ownerships $(X 4)$ have simultaneously direct effect on stock repurchase $(Y)$.

H2: Undervaluation $(X 1)$, free cash flow $(X 2)$, leverage $(X 3)$ and dispersion of ownerships $(X 4)$ have partially direct effect on stock repurchase $(Y)$.

\section{Methods}

The object of this research is those firms that implement Stock repurchase during 2010 until 2014, while the units of analysis in this research are the Annual Reports and Financial Reports of the companies that are listed on IDX and have been audited. From those observation units, the author observes the undervaluation $(X 1)$, free cash flow $(X 2)$, leverage $(X 3)$ and dispersion of ownerships $(X 4)$ and their influence toward stock repurchase $(Y)$. Those are explained in details as shown in Table 1.

TABLE 1. Qualitative research design

\begin{tabular}{|c|c|c|}
\hline Research Variables & Indicator & Item Measurement Instruments \\
\hline Undervaluation $(X 1)$ & $\begin{array}{l}\text { Price to book value } \\
\text { ratio }(\mathrm{P} / \mathrm{B} \text { or } \mathrm{MKBK})\end{array}$ & $\begin{array}{l}\text { Market value of equity-debt/ } \\
\text { Book value of assets }\end{array}$ \\
\hline Free cash flow $(X 2)$ & Free cash flow $\left(\mathrm{FCF}_{i(t-1)}\right)$ ratio & Ratio $\mathrm{FCF}_{i(t-1)} /$ total asset \\
\hline Leverage $(X 3)$ & Leverage $(L E V)$ ratio $_{i(t-1)}$ & Total debt/total asset \\
\hline Dispersion of ownerships $(X 4)$ & Dispersion of ownership (DIS) $)_{i(t-1)}$ & LNCAP \\
\hline Stock repurchase $(Y)$ & $\mathrm{REP}_{i t}$ & Stock repurchase valueit/market equity ${ }_{i(t-1)}$ \\
\hline
\end{tabular}




\section{Sampling Criteria}

The methodology approach of this research has used 26 samples of companies with purposive sampling method to determine 'sample criteria' on public listed companies listed in period of 2010-2014, which consistently publish their stock repurchase Announcement Report on the database of IDX.

TABLE 2 . Sample research

\begin{tabular}{llllll}
\hline \hline No & Company & Kode & No & Company & Kode \\
\hline 1 & PT. Multifiling Mitra Indonesia Tbk & MFMI & 14 & PT. Jaya Agra Wattie Tbk & JAWA \\
2 & PT. Bank Sinarmas Tbk & BSIM & 15 & PT. Buana Listya Tama Tbk & BULL \\
3 & PT. Krakatau Steel (Persero) Tbk & KRAS & 16 & PT. Mitrabahtera Segara Sejati Tbk & MBSS \\
4 & PT. Indofood CBP Sukses Makmur Tbk & ICBP & 17 & PT. Garuda Indonesia Tbk & GIAA \\
5 & PT. Golden Retailindo Tbk & GOLD & 18 & PT. Waskita karya (Persero) Tbk & WSKT \\
6 & PT. PP (Persero) Tbk & PTPP & 19 & PT. Wismilak Inti Makmur Tbk & WIIM \\
7 & PT. Saranacentral Bajatama Tbk & BAJA & 20 & PT. Adi Sarana Armada Tbk & ASSA \\
8 & PT. Visi Media Asia Tbk & VIVA & 21 & PT. Gading Development Tbk & GAMA \\
9 & PT. Golden Energy Mines Tbk & GEMS & 22 & PT. MNC Sky Vision Tbk & MSKY \\
10 & PT. Indo Straits Tbk & PTIS & 23 & PT. Tiphone Mobile Indonesia Tbk & TELE \\
11 & PT. Sidomulyo Selaras Tbk & SDMU & 24 & PT. Multi Agro Gemilang Plantation Tbk & MAGP \\
12 & PT. Alkindo Naratama Tbk & ALDO & 25 & PT. Sarana Meditama Etropolitan Tbk & SAME \\
13 & PT. Tifa Finance Tbk & TIFA & 26 & PT. Pelayaran Nasional Bina Buana Raya Tbk & BBRM \\
\hline \hline
\end{tabular}

\section{Sample Research}

As shown in Table 2 below is the list of sample research of those 26 companies which are suitable with the criteria mentioned.

\section{DATA ANALYSIS}

The data provided were analyzed by utilizing multiple linear regression analysis and Analysis of Variance (ANOVA). Multiple linear regression analysis was managed using the Statistical Package for Social Sciences (SPSS) version 20.0. And, the data were extracted from the annual reports of financial reports published by companies listed on the IDX. In order to compute the ratios needed by each company, it used Microsoft Excel spreadsheet. And the data would be formatted and then exported to SPSS applications.

In order to get the assessment of the informative force of the regression model, ANOVA was directed to examine whether any of the independent variables had influences on the dependent variable by utilizing the following hypothesis:

$\mathbf{H}_{0}: \rho 1=\rho 2=\rho 3=\rho 4=0$ : That undervaluation $(X 1)$, leverage $(X 2)$, free cash flow $(X 3)$ and dispersion of ownership $(X 4)$ have no partially significant influence toward Company's stock repurchases $(Y)$.

H1: At least one $\rho$ is not equal to zero/ $\rho$ should be above or below zero: That undervaluation $(X 1)$, leverage $(X 2)$, free cash flow (X3) and dispersion of ownership (X4) have partially significant influence toward Company's stock repurchases $(Y)$.

If the null hypothesis is accepted, then there is no influence of independent variables towards stock repurchases. If the null hypothesis is rejected, then it shows influences of independent variables toward the dependent variables of stock repurchases.

In the regression model, to test the $F$ value, it was dictated by its noteworthy $p$ esteem got from the SPSS PC programming at Confidence level of 95 percent. The computed $F$ value $m$ was ascertained as taken after: Computed $F$ value $=$ mean sum of squares $/$ mean sum of error terms.

The technique utilized at appropriation and tried on the incomplete autonomous factors to characterize which one is significant, may utilize the following hypothesis:

$\mathbf{H}_{0}: \rho=0$ : That undervaluation (X1), leverage $(X 2)$, free cash flow (X3) and dispersion of ownership (X4) have no simultaneously significant influence toward Company's stock repurchases $(Y)$.

H1: $\rho \neq 0$ : That undervaluation $(X 1)$, leverage $(X 2)$, free cash flow (X3) and dispersion of ownership (X4) have simultaneously significant influence toward Company's stock repurchases $(Y)$.

If the null hypothesis is accepted, then there is an influence of the independent variables toward the stock repur- 
chases. If the null hypothesis is rejected, then the individual independent variable has influences toward the stock repurchase.

\section{Descriptive Analysis}

The descriptive data analysis of the minimum, maximum, mean and its standard deviations is shows in Table 3.

TABLE 3 . Descriptive statistics

\begin{tabular}{llllll}
\hline \hline & $\boldsymbol{N}$ & Minimum & Maximum & Mean & Std. Deviation \\
\hline MKBK & 26 & -.24 & 8.19 & 1.6532 & 2.10870 \\
LEV & 26 & .00 & .76 & .2992 & .22373 \\
FCF & 26 & -.94 & .65 & -.0421 & .33130 \\
DIS & 26 & 11.03 & 13.91 & 12.1258 & .73449 \\
REP & 26 & .00010 & .09180 & .0171846 & .02332700 \\
VALID N (listwise) & 26 & & & \\
\hline \hline Mean was found for undervaluation (MKBK) $(X 1)$ 1.6532 $(S D$ 2.10870), & \\
Mean for leverage (LEV) $(X 2)$ was 0.2992 $(S D$ 0.22373), Mean for free cash \\
flow (FCF) $(X 3)$ was - $0.0421(S D$ 0.33130), Mean for dispersion of owner- \\
ship (DIS) $(X 4)$ is 12.1258 (SD 0.73449) and, Mean for stock repurchases \\
(REP) $(Y) 0.0171846(S D 0.02552700)$
\end{tabular}

\section{DISCUSSION}

\section{Normality Test-Kolmogorov-Smirnov Test (KS Test)}

The Kolmogorov-Smirnov test (Chakravart \& Laha, 1967) was used to determine whether a sample of a population comes with a specific normal distribution. This is a step function that increases by $1 / N$ at the value of each ordered data point. Table 3 has shown that the significant amount shows 0.856 more than $\alpha 0.05$ which means that it has normal distributions.
TABLE 4. Kolmogorov-smirnov test (KS test)

\begin{tabular}{lll}
\hline \hline Statistical Test & Value & Status \\
\hline Kolmogorov-smirnov $Z$ & 0.606 & Normal distributions \\
Significant & 0.856 & \\
\hline \hline Note. From SPSS version 20.0 output, 2016
\end{tabular}

As we can see in Figure 2 the $P$-Plot has indicated that the equality of the distribution is normal. The normal probability plot shows a straight line, implying normality (Park, Ribière \& Schulte, 2004).

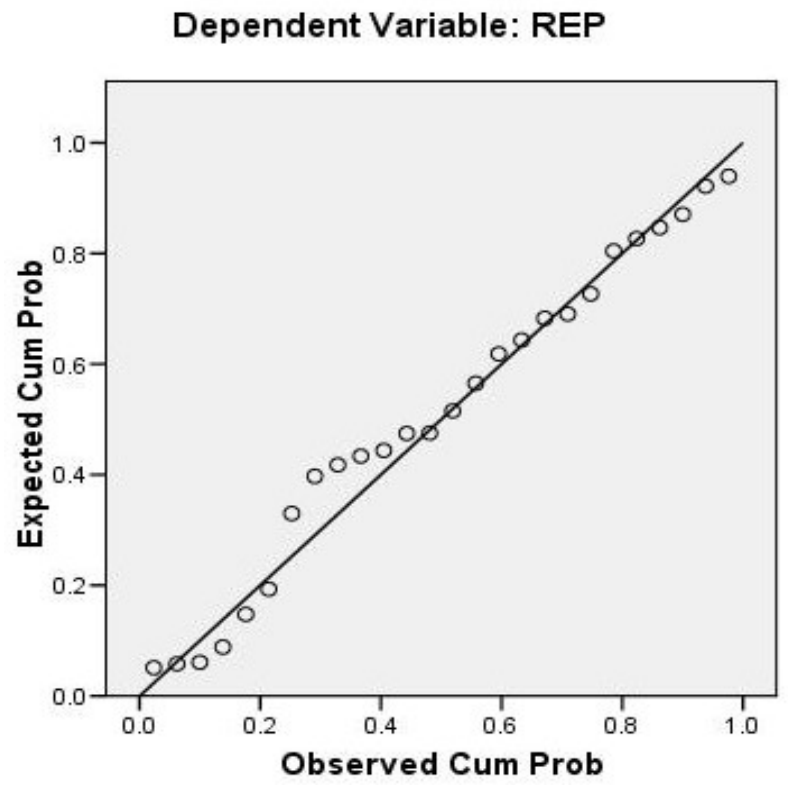

FIGURE 2 . Normal $P$-Plot of regression standardized residual 


\section{Multicollinearity Analysis}

According to Batterham, Tolfrey \& George (1997) this is an issue that happens when at least one free factors has a high connection with a blend of the other autonomous factors/independent variables on a regression analysis.

TABLE 5. Multicollinearity test

\begin{tabular}{lcc}
\hline \hline Independent Variable (Dimension) & (VIF) & Collinearity Statistic Remarks \\
\hline MKBK & 1.125 & Not multicoll \\
LEV & 1.577 & Not multicoll \\
FCF & 1.059 & Not multicoll \\
DIS & 1.428 & Not multicoll \\
\hline \hline Note. From SPSS version 20.0 output, 2016 &
\end{tabular}

\section{Heteroschedasticity Analysis}

Williams (2015) has stated that heteroschedasticity term is actually referred to as the error terms which do not have a constant variance (different variance). As shown in Table 6 the significant level for each independent variables is more than $5 \%$. Thus, it accepts the null hypothesis that the variance of the residuals is constant and it concludes that heteroscedasticity does not exist. In order to detect the existences of the heteroschedasticity, it can also be inferred from the pattern on graphical scatter plot. It shows that there is absolutely no heteroscedastity, because its pattern on graphical scatter plot has a completely random, equal distribution of points throughout the range of $\mathrm{X}$ axis and its spread above or under the 0 points on $Y$ axis. As see in the Figure 3. It shows that there is no heteroschedasticity existing, because the plots are spread throughout the graphics.

TABLE 6. Heteroschedasticity test-pearson correlation

\begin{tabular}{llc}
\hline \hline \multirow{4}{*}{ MKBK } & Abs Res \\
& Pearson correlation & -.373 \\
& Sig. (2-tailed) & .061 \\
\multirow{4}{*}{ LEV } & $N$ & 26 \\
& Pearson correlation & -.314 \\
& Sig. (2-tailed) & .119 \\
& $N$ & 26 \\
FCF & Pearson correlation & -.353 \\
& Sig. (2-tailed) & .077 \\
& $N$ & 26 \\
DIS & Pearson correlation & .233 \\
& Sig. (2-tailed) & .253 \\
\hline \hline Note. from SPSS version 20.0 output, 2016
\end{tabular}

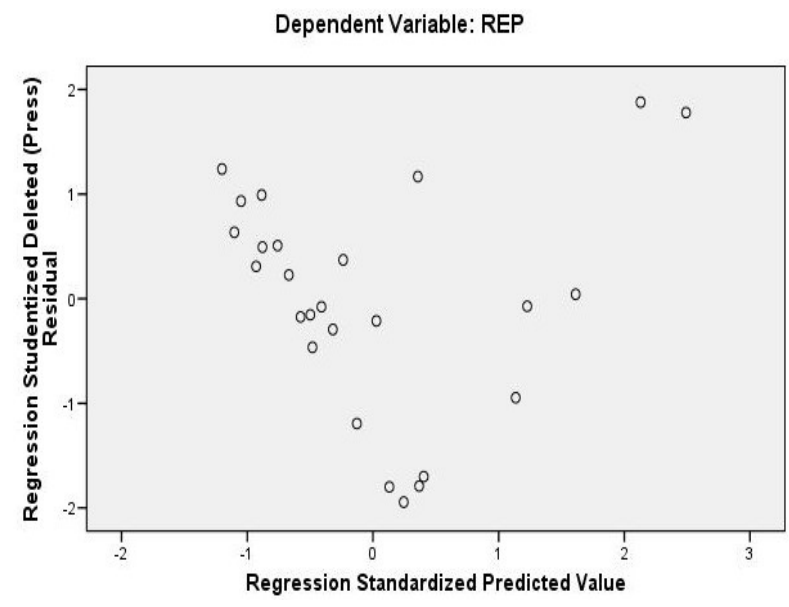

FIGURE 3. Scatter plot of the heteroschedasticity test

Autocorrelation Assumption Test-Durbin Watson Test The autocorrelation (Box, Jenkins, Reinsel \& Ljung, 2015) function can be utilized for the accompanying 2 goals:

1. Autocorrelation is utilized to recognize non-haphazardness in data (non randomness in data).

2. Autocorrelation is utilized to recognize a suitable time series data model of those non haphazard data.

According to Montgomery, Peck \& Vining (2001) a test for the residuals from the independent linear regression or multiple regression is considered as an Autocorrelation as it has been commented by them. 
TABLE 7. Durbin watson test

\begin{tabular}{|c|c|c|c|c|c|}
\hline Model & $\boldsymbol{R}$ & $R$ Square & Adjusted $R$ Square & Std. Error of the Estimate & Durbin-Watson \\
\hline 1 & $.885^{a}$ & .783 & .741 & .01297967 & 1.915 \\
\hline
\end{tabular}

According to Table 7 it shows that the Durbin-Watson coefficient is 1.915. And as showing in Table of DurbinWatson $d_{L}=1.061$ dan $d_{U}=1.759$ then it may consider that $d_{U}<d<4-d_{U}(1.759<1.915<2.241)$ and it may conclude that the errors are negatively autocorrelated.

\section{Regression Analysis}

From the SPSS linear regression output as in Table 8, the regression line was estimated as follows:

REP $=-0.213-0.001 \mathrm{MKBK}+0.054 \mathrm{LEV}-0.004 \mathrm{FCF}+0.018$ DIS $+\varepsilon$

The objective of this research was to establish the relationship and its influences between undervaluation (X1), free cash flow $(X 2)$, leverage $(X 3)$ and dispersion of ownerships $(X 4)$ toward company's stock repurchase $(Y)$ with 26 samples of IDX public listed companies. For achieving this objective, two sets of tests were carried out; an $F$ test for testing the overall significance of the regression model and a $t$ test for testing the significance of the independent variables partially in the regression model.

In this section, we present the results of our analysis, mainly regarding the relation between undervaluation (X1), free cash flow $(X 2)$, leverage $(X 3)$ and dispersion of ownerships (X4) toward company's stock repurchase $(Y)$. Based on the Regression analysis using SPSS version 20.0, it's been stated from table 6 that the Rsquare shows amount of 0.783 which means that all the dependent variables undervaluation (X1), free cash flow (X2), leverage (X3) and dispersion of ownerships $(X 4)$ have influence on the company's stock repurchase $(Y)$ for about $78.3 \%$. Or, it may consider that $21.7 \%$ is influence by other factors.

TABLE 8 . SPSS multiple regression analysis results

\begin{tabular}{lccc}
\hline \hline Variable & Coefficient & $\boldsymbol{t}$ & Sigh. \\
\hline Constant & -0.213 & & \\
Undervaluation $(X 1)$ & -0.001 & -0.961 & 0.347 \\
Leverage $(X 2)$ & 0.054 & 3.704 & 0.001 \\
Free cash flow $(X 3)$ & -0.004 & -0.528 & 0.603 \\
Dispersion of ownership $(X 4)$ & 0.018 & 4.221 & 0.000 \\
$R$ & $=0.885$ & & \\
$R$ Square & $=0.783$ & & \\
$F$ & $=18.924$ & & \\
$F$-Table $(d f 1=4, d f 2=21, \alpha=0.05)$ & $=2.840$ & & \\
Sig & $=0.000$ & & \\
$T$ & $=2.080$ & & \\
\hline \hline Note. Summary from SPSS version 20.0 output, 2016 & &
\end{tabular}

\section{Hypothesis Test-F-test}

For testing to the overall significance of the regression model, the $F$ test was carried out to assess whether there was a linear relationship between the independent variable Un dervaluation $(X 1)$, free cash flow $(X 2)$, leverage $(X 3)$ and dispersion of ownerships $(X 4)$ toward company's stock repurchase $(Y)$. ANOVA was performed to test whether any of the independent variables has influences on the depe-ndent variable. The results of the ANOVA are as shown in Table 9.
The $F$ test tested the following hypothesis:

$\mathbf{H}_{0}$ : Undervaluation (X1), leverage (X2), free cash flow (X3) and dispersion of ownership (X4) have no simultaneously significant influence toward Company's stock repurchases $(Y)$.

H1 : Undervaluation $(X 1)$, leverage $(X 2)$, free cash flow $(X 3)$ and dispersion of ownership (X4) have no simultaneously significant influence toward Company's stock repurchases $(Y)$. 
TABLE 9 . ANOVA results

\begin{tabular}{clccccc}
\hline \hline Model & & Sum of Square & $\boldsymbol{d} \boldsymbol{f}$ & Mean Square & $\boldsymbol{F}$ & Sig. \\
\hline \multirow{2}{*}{1} & Regression & .013 & 4 & .003 & 18.924 & $.000^{a}$ \\
& Residual & .004 & 21 & .000 & & \\
& Total & .016 & 25 & & & \\
\hline \hline
\end{tabular}

Note. a. Predictors: (Constant), DIS, MKBK, FCF, LEV

b. Dependent variable: REP

c. From SPSS version 20.0 output, 2016

From the ANOVA Table 9, the computed $F$ value of 18.924 is greater than the $p$ value of 0.000 and thus, it means that the null hypothesis was rejected. Therefore, it can be said that this study found a statistically significant influence of undervaluation $(X 1)$, leverage $(X 2)$, free cash flow (X3) and dispersion of ownership (X4) toward Company's stock repurchases $(Y)$. Based on above results it may conclude that stock repurchase can still be the best option for investors to distribute the excess fund, as we have seen that the indicators of investors based valuation also supported this issue. This research result is in line with the results from Elton \& Gruber (1968) who commented that some of the companies' shareholders will prefer to choose cash dividends and alternate stockholders might prefer to choose the stock repurchase for their money disbursement technique purposed. Therefore, the factors of the independent variables undervaluation (X1), leverage $(X 2)$, free cash flow (X3) and dispersion of ownership (X4) are still becoming the best consideration for stockholders in performing stock repurchase, thus, also supporting that the purpose of stock repurchase is to recover the decline of stock value. It is supported by the research from El Houcine (2013) that institutional investor's ownership has positive influence towards the repurchase of stocks which can likewise be clarified by the reality of appropriating the accessibility of the free cash flow in the form of repurchases as an additional method for choices for managers to control and maintain a strategic distance from assets extortion.

\section{Hypothesis Test $-t$-test}

In order to test for the significance of the independent variables, each coefficient of the independent variables was tested individually or partially using the $t$ test to assess whether there was a linear relationship and its influences on the independent variables undervaluation $(X 1)$, leverage $(X 2)$, free cash flow $(X 3)$ and dispersion of ownerships $(X 4)$ toward company's stock repurchase $(Y)$. The results from the SPSS regression output with regard to the independent variables are as shown in Table 10.

TABLE 10 . $T$-test results

\begin{tabular}{ccccccccc}
\hline \hline & & \multicolumn{2}{c}{ Unstandardized Coefficients } & \multicolumn{2}{c}{ Standardized Coefficients } & & \multicolumn{2}{c}{ Collinearity Statistics } \\
\cline { 2 - 5 } \cline { 3 - 4 } & Model & B & Std. error & Beta & & Sig. & Tolerance & VIF \\
\hline 1 & (constant) & -.213 & .049 & & -4.353 & .000 & & \\
& MKBK & -.001 & .001 & -.104 & -.961 & .347 & .889 & 1.125 \\
& LEV & .054 & .015 & .473 & 3.704 & .001 & .634 & 1.577 \\
& FCF & .004 & .008 & -.055 & -.528 & .603 & .944 & 1.059 \\
DIS & .018 & .004 & .513 & 4.221 & .000 & .700 & 1.428 \\
\hline \hline
\end{tabular}

Note. a. Dependent variable: REP

b. From SPSS version 20.0 output, 2016

\section{Hypothesis of undervaluation $(X 1)$ toward stock repur- chases $(Y)$}

The $t$ test tested the following hypothesis:

$\mathbf{H}_{0}$ : Undervaluation $(X 1)$ has no partially significant influence toward stock repurchase $(Y)$.

H1: Undervaluation (X1) has partially significant influence toward stock repurchase $(Y)$.

The sig. value of undervaluation (X1) is .347 greater than $0.05(\alpha 5 \%)$ and the $t$ value shows negative -.961 . Thus it means that the null hypothesis with regard to these independent variables was accepted. Hence, this study found that undervaluation (X1) has partially no significant influence toward Stock Purchase $(Y)$. The results are also suitable with the research from Liang et al. (2013) which stated that undervaluation of shares is not the reason why company decides to buy back shares (share/stock repur chases). Also, the research from D'mello \& Shroff (2000) has found that undervaluation prediction can't preclude 
the free cash flow motivation for stock repurchases. It implies the presumptions that most companies actually do 'buy back' mostly not as a result of the undervaluation motive but simply because of the company still concerning the dispersion of ownerships, so, the majority shareholders still could be able to take control of the company and make the decision.

\section{Hypothesis leverage $(X 2)$ toward stock repurchases $(Y)$}

The $t$ test tested the following hypothesis:

$\mathbf{H}_{0}$ : Leverage $(X 2)$ has no partially significant influence toward stock repurchases $(Y)$.

H1: Leverage $(X 2)$ has partially significant influence toward stock repurchases $(Y)$.

The sig. value of leverage $(X 2)$ is .001 less than 0.05 ( $\alpha 5 \%$ ) and the $t$ value shows positively as 3.704. Thus it means that the null hypothesis with regard to these independent variables was rejected. Therefore, this study found that leverage $(X 2)$ has partially significant influence toward stock repurchases $(Y)$. The results are also suitable with the note of signaling model similar to the one created by Ross (1977) who contends that of a positive signal on financial leverage. Also, it supported the theory from Heydary et al. (2014) that depicts the nearness of a positive relationship between financial leverage and performance. Thus, it then turns in to an interest factor from the stockholders to do stock repurchases. It implies that the companies have more intention to increase leverage in order to control the company by doing 'buyback'.

\section{Hypothesis free cash flow (X3) toward stock repur- chases $(Y)$}

The $t$ test tested the following hypothesis:

$\mathbf{H}_{0}$ : Free cash flow $(X 2)$ has no partially significant influence toward stock repurchase $(Y)$.

H1: Free cash flow $(X 3)$ has partially significant influence toward stock repurchase $(Y)$.

The sig. value of free cash flow (X3) is .603 greater than $0.05(\alpha 5 \%)$ and the $t$ value shows negative - .528. Thus it means that the null hypothesis with regard to these independent variables was accepted. Hence, this study found that free cash flow (X3) has partially no significant influence toward the Stock Purchase $(Y)$. The results are also in line with the research of Chan et al. (2010), which reported the free cash flow wwas not connected to the abnormal returns of its repurchase program. However it was rather connected to choices to change the companies' adapting levels and signal managerial trust in future income levels.
It might imply that the management has a strong intention to invest the money in the operational company in order to provide more profit and the management prefers the cash dividend.

\section{Hypothesis Dispersion of ownership (X4) toward stock repurchases $(Y)$}

The $t$ test tested the following hypothesis:

$\mathbf{H}_{\text {) }}$ : dispersion of ownership (X4) has no partially significant influence toward stock repurchases $(Y)$.

H1: dispersion of ownership (X4) has partially significant influence toward stock repurchases $(Y)$.

The sig. value of dispersion of ownership (X4) is .000 less than 0.05 ( $\alpha$ 5\%) and also the $t$ value shows positively as 4.221. Thus it means that the null hypothesis with regard to these independent variables dispersion of ownerhips (X4) was rejected. Therefore, this study found that dispersion of ownership (X4) has partially significant influences toward stock repurchases $(Y)$. The result are also suitable with Skjeltorp \& Odegaard (2004) which has found that the trend for firms with a particular true objective to pronounce their repurchase program and lead their stock repurchases is relies upon the ownership structures. It implies that the company is more interested in the stock repurchase to increase their ownership structure of the company regarding the objective to take control of the company and increase the potential returns in the form of dividends.

\section{Implications of the Hypothesis Test}

The results of the research mainly of the $F$ Test Hypothesis create the implication that all those independent variables still become a major attentions for the company to do the 'buy back' for many purposes such as a). To protect the stock value during the crisis, as we know that during the period of research (2010-2014) the uncertainty or global crisis had already happened in Europe, due the debt/bankruptcy scandals of the Greek; b). To increase the dispersion of ownerships of the major shareholder in order to take control of the company. But, it is still open on further research that any others factors except those 4 (Four) independent variables undervaluation $(X 1)$, leverage $(X 2)$, free cash flow $(X 3)$ and dispersion of ownership (X4) which might have influences toward the stock repurchase. And, other options except doing 'buy back' in order to recover from the de crease of stock value as the option of company's action during the market crisis or otherwise for the shareholders main objective to take control of the company. 


\section{CONCLUSION}

This study provides a detailed examination of the influence of undervaluation, free cash flow, leverage and dispersion of ownerships toward company's stock repurchase (An Empirical Study of Indonesia Stock Exchange Public Listed Companies). The main motivation is that stock repurchase is an important corporate event, whose benefit is to recover the decrease of stock value from the market which mostly caused by the negative sentiment from the investors, especially during the crisis. The study has provided the results that are theoretically in line. The study on F-test has found a statistically significant influence of undervaluation (X1), leverage (X2), free cash flow (X3) and dispersion of ownership (X4) toward Company's stock re purchases $(Y)$. Based on above results it may be concluded that stock repurchase is still the best option for investors to distribute the excess fund, as we have seen that the indicators of investors based valuation also supported this issue. This result is in line with the results from Elton \& Gruber (1968) whereas in any corporation's there will usually be some stockholders who will lean cash dividends and some who will incline stock repurchase as a method of cash disbursement. Based on the $t$ test to assess whether there was a linear influence of the independent variables undervaluation (X1), leverage $(X 2)$, free cash flow $(X 3)$ and dispersion of ownerships $(X 4)$ toward company's stock repurchase $(Y)$, the study has shown that leverage and dispersion of ownerships show a positive and significant influence toward the company's stock repurchase. It is contrary to the 2 (Two) other variables which are undervaluation and free cash flow having negative signaling toward the company's stock repurchase.

\section{REFERENCES}

Andriosopoulos, D., \& Lasfer, M. 2015. The market valuation of share repurchases in Europe. Journal of Banking \& Finance, 55: 327-339. DOI: $10.2139 /$ ssrn.1333687

Adel, B. 2014. Asymmetric information and payout policy: Dividend or share repurchase. International Review of Man- agement \& Business Research, 3(2): 753-745.

Amelia, N. 2016. Causality test between exchange rate, inflation rate and stock price index in Southeast Asia Tifa. Journal

of Administrative and Business Studies, 2(2): 101-106. D0I: 10.20474/jabs-2.2.5

Batterham, A.M., Tolfrey, K., \& George, K.P. 1997. Nevill's explanation of Kleiber's 0.75 mass exponent: An artifact of collinear- $\quad$ ity problems in least squares models? Journal of Applied Physiology, 82: 693-697.

Bhana, N. 2007. The market reaction to open market share repurchases announcements: The South African experience.

Investment Analysts Journal, 65: 25-36.

Bharucha, J. 2016. Taking ownership of the future: Developing practical money skills among the youth in emerging economies.

International Journal of Business and Economic Affairs, 1(1): 13-20. D0I: 10.24088/ijbea-2016-11003

Box, G.E., Jenkins, G.M., Reinsel, G.C., \& Ljung, G.M. 2015. Time series analysis: Forecasting and control. San Francisco, CA: John Wiley \& Sons.

Brav, A., Graham, J.R., Harvey, C.R., \& Michaely, R. 2005. Payout policy in the 21st century. Journal of Financial Economics, 77(3): 483-527. DOI: 10.3386/w9657

Brockman, P., \& Chung, D.Y. 2001. Managerial timing and corporate liquidity: Evidence from actual share repurchases. Jour- nal of Financial Economics, 61(3): 417-448.

Chakravarti, I.M., \& Laha, R.G. 1967. Handbook of methods of applied statistics. New York, NY: John Wiley \& Sons.

Chan, K., Ikenberry, D.L., Lee, I., \& Wang, Y. 2010. Share repurchases as a potential tool to mislead investors. Journal of Corporate Finance, 16(2): 137-158. DOI: 10.2139/ssrn.1485583

Cook, D.O., Krigman, L., \& Leach, J.C. 2003. On the timing and execution of open market repurchases. The Review of Finan- cial Studies, 17(2): 463-498. DOI: 10.2139/ssrn.251854

Dann, L.Y. 1981. Common stock repurchases: An analysis of returns to bondholders and stockholders. Journal of Financial

Economics, 9(2): 113-138. DOI: 10.1016/0304-405x(81)90010-6

Dittmar, A.K. 2000. Why do firms repurchase stock. The Journal of Business, 73(3): 331-355. DOI: 10.1086/209646

D'mello, R., \& Shroff, P.K. 2000. Equity undervaluation and decisions related to repurchase tender offers: An empirical investigation. The Journal of Finance, 55(5): 2399-2424. DOI: 10.1111/0022-1082.00292

El Houcine, R. 2013. Ownership structure and stock repurchase policy: Evidence from France. Accounting \& Taxation, 5(2): $\quad 23-28$. 
Elton, E., \& Gruber, M. 1968. The effect of share repurchase on the value of the firm. The Journal of Finance, 23(1): 135-149. DOI: $10.2307 / 2325917$

Firth, M., \& Yeung, C.S. 2005. An empirical investigation of share buybacks in Hong Kong. Journal of Emerging Market Finance, 4(3): 207-225. DOI: 10.1177/097265270500400301

Fu, T. C., Chung, F. L., Luk, R., \& Ng, C.M. 2007. Stock time series pattern matching: Template-based vs. rule-based approaches. Engineering Applications of Artificial Intelligence, 20(3): 347-364.

Ginglinger, E., \& L'her, J.F. 2006. Ownership structure and open market stock repurchases in France. European Journal of Finance, 12(1): 77-94. DOI: 10.1080/13518470500039543

Grullon, G., \& Michaely, R. 2004. The information content of share repurchase programs. The Journal of Finance, 59(2): 651-680. DOI: 10.1111/j.1540-6261.2004.00645.x

Grullon, G., Michaely, R., \& Swaminathan, B. 2002. Are dividend changes a sign of firm maturity? The Journal of Business, 75(3): 387-424. DOI: 10.1086/339889

Heydary, I., Mirza, M., \& Javadghayedi, M. 2014. Investigating the relationship between cash flow and firm performance: Evidence from tehran stock exchange. Indian Journal of Scientific Research, 4(6): 269-279.

Horne, V. J., \& Wachowicz, J. 2005. Fundamentals of financial management edisi kedua belas. Jakarta, Indonesia: Salemba Empat.

Hosban, A.A. 2016. Accounting disclosure for stock goods and industrial companies IAS 2-An analytical study of industrial companies listed on the Amman Stock Exchange. International Journal of Business \& Administrative Studies, 2(2): 24-28. DOI: 10.20469/ijbas.2.10001-2

Hsu, A., \& Utami, F. 2016. Central bank intervention and stock market response. International Journal of Business \& Ad- ministrative Studies, 2(5): 151-161. DoI: 10.20469/ijbas.2.10005-5

Hussin, B.M., Ahmed, A.D., \& Ying, T. C. 2010. Semi-strong form efficiency: Market reaction to dividend and earnings an- nouncements in Malaysian stock exchange. IUP Journal of Applied Finance, 16(5): 36-45.

Hyderabad, R.L. 2009. Market reaction to buy-back announcement in India. Journal of Applied Finance, 15(12): 53-77.

Ikenberry, D., Lakonishok, J., \& Vermaelen, T. 2000. Stock repurchases in Canada: Performance and strategic trading. The

Journal of Finance, 55(5): 2373-2397. D0I: 10.3386/w7325

Investopedia. 2015. Undervalued what does 'Undervalued' means? URL: goo.gl/Y8GfBU. Last accessed on 20 May 2017. Jagannathan, M., Stephens, C.P., \& Weisbach, M.S. 2000. Financial flexibility and the choice between dividends and stock re- $\quad$ purchases. Journal of Financial Economics, 57(3): 355-384. DOI: 10.2139/ssrn.148548

Jensen, M.C. 1986. Agency costs of free cash flow, corporate finance, and takeovers. The American Economic Review, 76(2):

323-329. DOI: $10.1017 /$ cbo9780511609435.005

Kinsler, N.A., \& Bacon, F.W. 2008. Stock repurchase announcements: A test of market efficiency. American Society of

Busi- $\quad$ ness \& Behavioral Sciences, 4(1): 34-45.

Kurniawan, M.Z., \& Moeljadi, S. 2013. Performance analysis of companies go public in Indonesia doing stock buyback policy.

European Journal of Business \& Management, 5(22): 23-30.

Liang, W.L., Chan, K., Lai, W. H., \& Wang, Y. 2013. Motivation for repurchases: A life cycle explanation. Journal of Financial Services Research, 43(2): 221-242. D0I: 10.1007/s10693-011-0126-7

Lie, E. 2005. Operating performance following open market share repurchase announcements. Journal of Accounting \& Economics, 39(3): 411-436. DOI: 10.1016/j.jacceco.2005.04.001

Liljeblom, E., \& Pasternack, D. 2006. Share repurchases, dividends and executive options: The effect of dividend protection.

European Financial Management, 12(1): 7-28. DoI: 10.1111/j.1354-7798.2006.00308.x

Montgomery, D.C., Peck, E.A. \& Vining, G.G. 2001. Introduction to linear regression analysis. New York, NY: John Wiley \& Sons.

Ofer, A.R., \& Thakor, A.V. 1987. A theory of stock price responses to alternative corporate cash disbursement methods: Stock repurchases and dividends. The Journal of Finance, 42(2): 365-394.

DOI: $10.1111 / \mathrm{j} .1540-6261.1987 . t b 02572 . x$

Pacheco, L.K., \& Raposo, C. 2007. The determinants of initial stock repurchases. URL: goo.gl/Ymzag8. Last accessed on 20 June 2017. 
Park, H., Ribière, V. , \& Schulte Jr, W.D. 2004. Critical attributes of organizational culture that promote knowledge manage- ment technology implementation success. Journal of Knowledge Management, 8(3): 106-117.

Peraturan Nomor XI.B.2. 1998. Keputusan ketua bapepam. URL: goo.gl/9Mj1mG. Last accessed on 18 April 2017.

Peraturan X.K.1. 1996. Keputusan ketua bapepam. URL: goo.gl/j9Dq3cG. Last accessed on 18 April 2017.

Peyer, U., \& Vermaelen, T. 2008. The nature and persistence of buyback anomalies. The Review of Financial Studies, 22(4): 1693-1745. DOI: $10.1093 / \mathrm{rfs} / \mathrm{hhn} 024$

Purnamasari, K., \& Fitdiarini, N. 2016. Corporate diversification and cash holding. Journal of Administrative \& Business

Studies, 1(1): 21-27. DOI: 10.20474/jabs-1.1.4

Ross, S.A. 1977. The determination of financial structure: The incentive-signalling approach. The Bell Journal of Economics, 8(1): 23-40. DOI: 10.2307/3003485

Skjeltorp, J.A., \& Odegaard, B.A. 2004. The ownership structure of repurchasing firms. Working paper, Norway and Nor- $\quad$ wegian School of Management (BI), Oslo, Norway.

Stephens, C.P., \& Weisbach, M.S. 1998. Actual share reacquisitions in open-market repurchase programs. The Journal of

Finance, 53(1): 313-333. DOI: 10.1111/0022-1082.115194

Vermaelen, T. 1981. Common stock repurchases and market signalling: An empirical study. Journal of Financial Eco- $\quad$ nomics, 9(2): 139-183. DOI: 10.1016/0304-405x(81)90011-8

Wansley, J.W. , Lane, W. R., \& Sarkar, S. 1989. Managements' view on share repurchase and tender offer premiums. Financial

Management, 18(3): 97-110. DOI: /10.2307/3665652

Williams, R. 2015. Heteroskedasticity. Unpublished doctoral dissertation, University of Notre Dame, Indiana, IN.

— This article does not have any appendix. - 